\title{
Kentlileşememenin Nedeni Olarak Yabancılaşma ve Anomi ${ }^{*}$
}

\author{
Coşkun San ** \\ $\ddot{O} z e t$
}

Bu çalışmada, Kocaeli Üniversitesi'nde gerçekleştirilen "Kentleşme Bilinci” konulu, 19. Yaratıcı Drama Semineri'ndeki konuşmadan hareketle, kentlileşememe olgusuna kırsal-kentsel değerlerin farklılıkları sonucunda ortaya çıkan "kültür çatışması"nın neden olduğu; söz konusu çatışmanın ise, yabancılaşma ve anomi süreçlerini doğurduğu; böylece kentlileşmenin 2 ile 3 kuşak sonrasina ertelenmek zorunda kalındı ğı anlatılmaktadır.

Anahtar Sözcükler: Kentlileşme, yabancılaşma, anomi, kültürel çatışma, kültür şoku.

\begin{abstract}
This study is based on the talk about 'The conscious of becoming urbanized given at 19. Creative Drama Seminar in Kocaeli University. In this study, it was explained that 'cultural conflict emerged from rural-urban value differences result in the phenomenon of not being able to be urban people. This conflict generates the process of alienation and anomie. Therefore, becoming urbanized will be postponed to the second and third generations.
\end{abstract}

Keywords: Becoming urbanized, alienation, anomie, cultural conflict, culture shock.

1. Kavramsal Açıklama: Tek tek birer tez konusu olabilecek aşağıdaki kavramlar, ayrıntılara girilmeksizin özleri açısından ve yüzeysel bir biçimde tanımlanmaya çalışılacaktır.

Kentlileşme, ekonomik, siyasal, toplumsal vb. nedenlerle iç ya da dış göç yoluyla kırdan kente gelen bireylerin belli bir süre içinde kent değerlerini ve kentlilerin davranış kalıplarını benimseyerek onlar gibi yaşamaya başlamaları şeklinde tanımlanabilir.

Yabancılaşma, ağırlıklı biçimde ekonomik, sonra da siyasal, toplumsal vb. nedenlerle, bireyin kendini güçsüz, varlığını ise anlamsız olarak duyumsayarak, belli bir kuralsızlık (anomi) ortamına savrulması, böylece Marx'ında belirttiği üzere çevresine ve özüne yabancılaşması şeklinde özetlenebilir.

Anomi'ye gelince, burada asıl vurgu bağlayıcılığı bulunan davranış kurallarının çokluğu üzerinedir ve genellikle toplumlarda Durkheim ve Merton'un belirttiği gibi çeşitli nedenlerle ortaya çıkan köklü değişimler sonucunda kendini gösterir.

\section{Göçerlikten Köylülüğe ve Kentliliğe Geçiş:}

Avcılık ve toplayıcılık aşamasında insanlar, belli aralıklarla yer değiştirmek, böylece daha elverişli avlaklara ve topraklara ulaşmak zorunda kaldıkları için, sürekli yerleşmeler oluşturma gereğini duymamışlardır. Duvarlarına resimler yaptıkları mağaralarda insanlar, kuşaktan kuşağa binlerce yıl kalmış olmakla birlikte, zaman zaman göçmek zorunda kaldıkları için, bu yerlerin kalıcı barınaklar olarak kabul edilmesi zordur. İlk kalıcı yerleşmeler, insanların avcılık ve toplayıcılık yanında, kimi hayvan türlerini evcilleştirmeleri ve toprağı işlemeye başlamaları ile olanak kazanmıştır. Kazıbilimin son buluntularına göre günümüzden yaklaşık 10 bin yıl kadar öncesinde ilk kalıcı yerleşmelerin oluşmaya başladığı görülmektedir. Hacılar, Çatalhöyük, Nevali, Çori, bu ilk kalıcı yerleşmelere örnek

\footnotetext{
* 19.Yaratıcı Drama Seminerinde bildiri olarak sunulmuştur.

** Prof. Dr., Ankara Üniversitesi Siyasal Bilimler Fakültesi Emekli Öğretim Üyesi.
} 
olarak verilebilir. İşte bu ilk kalıcı yerleşmeler, üretim biçimi açısından hayvancılık ve tarıma dayandıkları, görece küçük bir nüfus barındırdıkları, böylece toplumsal denetim ve dayanışmayı çok sıkı bir biçimde uyguladıkları için, köysel yerleşmeler sayılırlar.

Kentlerin hangi tarihte oluşmaya başladıkları konusu çok tartışılmıştır. Bunun başlıca nedeni, göçerlikten yerleşikliğe geçişin daha belirgin kanıtlarının bulunmasına karşılık, köyden kent düzenine geçişin aşamalı bir biçimde gerçekleşmesi ve bu sürecin karmaşık bir nitelik göstermesidir. Kentlerin köylerden farklılaşmasına etki eden temel ögeleri siyasal, ekonomik ve hukuksal değişimler şeklinde sıralamak olanaklıdır. Göçerlerde ve köylülerde, genellikle seçilen ya da kendini seçtiren bir önder (şef) yanında bir de yaşlılar kurulu (gerontokrasi) bulunmasına karşı1lık, kentleşme sürecinde, siyasal işlevlerin çeşitlendiği, böylece yönetsel yapının genişleyerek farklılaştığı görülmektedir.

Köysel yerleşmeler içe dönük ve kapalı oluşumlar oldukları halde, kentler kural olarak dışa dönük ve açık oluşumlardır. Bu durum nedeniyle de, iş bölümü artmakta hemen hemen her işi benzer şekilde yerine getiren köylü, belli konularda uzmanlaşmaya başlayan kentliye dönüşmektedir.

Ekonomik açıdan ortaya çıkan yenilik ise, kentin çeperlerinde henüz tarım ve hayvancılık etkinlikleri sürdürülmekle birlikte, ağırlığın yavaş yavaş başka bir üretim tarzı olan imalat ve ticarete kaymaya başlamasıdır. Çanak-çömlek yapımı, demircilik, dokumacılık gibi zanaat alanları gelişmekte ve üretilen malların dış dünyaya pazarlanması için kervanlar düzülmekte ve denize yakın olan yerleşmelerde ilkel deniz taşıtları yapılmaktadır. Kuşkusuz köysel yerleşmelerde de, ürettikleri ürünleri gereksinim duydukları diğer yaşamsal maddelerle değiş tokuş etme etkinliği vardır ama bu etkinlik hiçbir zaman kentsel ticaret oylumuna ulaşamamıştır.

Hukuksal açıdan da, derin bir farklılaşma kendini göstermektedir. Geleneksel hukuk kuralları yanında, yazının bulunmasından başlayarak özellikle ticarete ilişkin temel ilkelerin yazılı hâle gelmeye, ayrıca kimi sözleşmelerin kil tabletler üzerine yazılmaya başlandığına tanık olunmaktadır. Ayrıca insanların birkaç yüz kişilik yerleşmelerden binlerce kişinin bulunduğu kentlerde yaşamaya başlamaları, zorunlu olarak hukuksal çatışmaları da olağanüstü artırmaya başlamış, böylece giderek dinden bağımsızlaşan yargı organı da belirmekte gecikmemiştir.

Ana hatları ile açıklanmaya çalışılan köylerin bir kısmının kentlere evrilmesi süreci, farklılaşan ve çeşitlenen siyasal, ekonomik ve hukuksal işlevlerin doğurduğu gereksinimler sonucunda, güçlü bir biçimde kentsel yerleşimlerin mimarisine de yansımış̧ır. Eski köysel yerleşmelerde konutlar birbirlerine bitişik düzende, girişleri tavandan yapılır, kutsal yerleri hatta mezarları evin içinde bulunurken (içe dönüklük ve dışa kapalılık), ilk kentlerde kamusal alanların ve yapıların, ayrıca pazar ve kısmen de eğlence yerleri yanında mezarlıkların da (dışa dönüklük ve dışa açıklık) oluşmaya başladığı görülmektedir.

\section{Kırsal ve Kentsel Kültürün Temel Nitelikleri:}

Kırsal yerleşmeler ile kentlerin oluşum sürecinde her iki yerleşim biçimi de, kültürel açıdan birbirinden büyük ölçüde farklılaşmaya başlar. Kırsal kültür güçlü geleneklerin güdümünde, katı bir toplumsal hiyerarşi, yakın bir toplumsal denetim ve etkili bir dayanışmaya dayalı tekçi (monist) bir yapı oluşturur. Kırsal kültürün meşruluk temelinde yüzlerce, binlerce yıldır kuşaktan kuşağa, belli belirsiz değişikliklerle aktarılan kırsal gelenekler bulunur. Söz konusu gelenekler öylesine güçlüdürler ki, toplumsal yaptırımlar genellikle yasal yaptırımların önüne geçer (töre cinayetleri, kan gütme vb.) ve kültürün çok önemli görmediği kimi toplumsal sapmalar ise örtbas edilir.

Tüm bunlara karşılık kentsel kültür, yasaların başat olduğu bir ortamda, zaman içinde yumuşayan bir toplumsal hiyerarşi, giderek gevşeyen bir toplumsal denetim ve büyük ölçüde kamusal yardımlara dayalı çoğulcu (plüralist) bir yapıyı ortaya çıkarır. Kentsel kültürün meşruluk temeli, yavaş yavaş yazılı hale gelmeye başlayan ve gereksinimlere göre değişebilen yasalardır. Yaptırımlar kamusal örgütlerce karara bağlanıp (yargı organları) gene bu çerçevede uygulanırlar (ceza infaz kurumları). 
Görüldüğ̈̈ gibi, ana hatlarıyla betimlenmeye çalış1lan kırsal ve kentsel kültürün temel nitelikleri alman sosyolog Tönnies'in "cemaat" ve "cemiyet" tipolojisi ile belirgin bir benzerlik göstermektedir.

İşte neredeyse birbirlerine taban tabana zit bu iki kültürün ürünü olan bireylerin bir arada yaşamak zorunda kalışları, ortaya bir kültürel çatışmanın (cultural clash) çıkmasına neden olur ki, bunun sonucunda yabancılaşma ve anomi diye adlandırılan durumlar belirir.

\section{Kırsal ve Kentsel Kültür Çatışmasının Ürünü Olarak Yabancılaşma ve Anomi:}

Belli bir kültürün temel değerleri yönünde toplumsallaşan bireyin, farklı bir kültür ortamına girmek zorunda kaldığında, bir tür kültür şoku yaşaması ve uyum sorunlarıyla karşı karşıya gelmesi kaçınılmazdır. Bu durum, yalnızca kırdan kente göçenler için değil, kısa ya da uzun bir süre kırda yaşamak durumunda kalan kentliler için de söz konusudur. Eğer bir birey, kendi ülkesinin kent kültürüne bile yabancı iken, başka bir ülkedeki kentte yaşamak zorunda kalırsa, yabancılaşma olgusunun katlanarak artması ve bireyin ruhsal sağlığını bile tehdit edebilecek boyutlara ulaşması, kesinlikle şaşkınlık yaratmamalıdır.

Kırsal kültürün değerleri yönünde toplumsallaştırılan birey, geleneklere uygun davrandığ sürece kırda belli bir statüye sahip iken, kentte bu konumu kökten sarsılmakta, edindiği toplumsal değerlerden çok farklı dünya görüssleriyle karşılaşmakta, doğal olarak bunlara uyum sağlayamayınca da kentlilerce dışlanmaya uğramaktadır. Maddi yaşam koşullarının da kırdan çok farklı olması tüm bunlara eklenince, bireyin kendini bir kültürler çatışması ve dolayısıyla bir kültür şoku içinde bulması kaçınılmaz olmaktadır.

İşte bu durumda, kır kökenli birey kendini güçsüz ve varlığını anlamsız olarak duyumsamaya, böylece önce çevresine sonra da kendi özüne bile yabancılaşmaya başlayacaktır. Kırdan kente göçün ülkemizde ve benzer ülkelerde görüldüğ̈̈ gibi, daha önce var olan kent nüfusunun çok üstündeki sayılarda gerçekleştiği ortamlarda, yabancılaşma olgusunun bu kez kentlileri de etkisi altına alması ve bireylerin kendi kentlerine yabancılaşmaya başlamaları, gözlemlenen bir başka toplumsal gerçektir.

Kırsal ve kentsel kültürlerin çatışması, ayrıca kırdan kente göçen bireyler açısından anomik bir ortamın da doğmasına neden olmaktadır. Anomi bilindiği gibi köklü değişimlerde (devrim, göç) ve öncelikle çağımızdaki geçiş toplumlarında sıklıkla görülen çok kurallılık ve kuralsızlık durumudur. Geleneksel ve çağcıl (modern) değerlerin çatışması, hangisine öncelikle uyulması gerektiği hakkında kararsızlığın egemen olduğu, kimi birbiriyle çelişen bir dizi kural ortaya çıkarmakta, benzer durumların artması sonucunda ise birey, hiçbirine uymayarak kuralsızlık uçurumuna savrulabilmektedir. Kurallara zaman zaman ya da hiçbir zaman uymamak, kesin bir biçimde suçluluk olgusunda da artışa neden olmaktadır.

\section{Bir Tampon Düzenek Olarak Hemşehrilik:}

Kıray'ın da değinmiş olduğu tampon mekanizmalar, bir toplumsal durumdan diğerine geçişte kültürel, toplumsal, ekonomik vb. çatışmaların şiddetini azaltacă̆ 1 düşünülen ara çözümlerdir. Hemşehrilik düzeneği, gerek dış gerekse iç göçlerde sıklıkla rastlanan ve büyük bir olasılıkla yakın gelecekte de etkisini yitirmeyecek gibi görünen bir olgudur. En genel anlamındaki hemşehrilik, yalnızca aynı yerleşim yerinden olmayı değil, belli durumlarda aynı etnik, dinsel ya da topluluk (cemaat) grubunun üyesi olmayı da kapsayabilir. Büyük sayılarda dış göç almış olan ABD, Kanada, Avustralya gibi ülkelerde, öncelikle etnik aidiyete dayalı hemşehrilik düzeneğinin, önemli roller oynadıkları bilinmektedir. Başlangıçta kalıcı olmayacağı varsayılan Avrupa ülkelerine işçi göçlerinde de benzer düzeneğin devreye girdiği görülmüştür.

Ülkemizde, kırdan kente göç olgusunda da aynı düzenek işlemiştir ve işlemeyi sürdürmektedir. Gerçekten de, bir tampon düzenek olarak hemşehrilik kırdan gelenlerin geçici olarak barınmalarını, karınlarını doyurmalarını ve iş bulmalarını sağlayan bir işlev görmektedir. Ayrıca yeni gelenler, daha 
önce kente yerleşen hemşehrilerince neleri yapıp, neleri yapmamaları konusunda uyarılmakta, böylece anomik durumlara düşmeleri önlenmeye çalışılmaktadır.

Hemşehrilik düzeneğinin olumlu sayılabilecek yanı, kültürler çatışmasında bir tampon görevi görmesi olmakla birlikte, özellikle gecekondulu ya da gecekondu apartmanlı varoşlarda, bir tür getto oluşturdukları, kırsal değerleri kendi yaşam alanlarında sürdürdükleri düşünülecek olursa, kentle bütünleşmeyi geciktirdikleri de söylenebilir.

\section{Kentlileşmeyi İvedi Olarak Gerçekleştirmek Olanaklı mıdır?}

Bireyin ekonomik, siyasal, toplumsal vb. zorunluluklar nedeniyle içine girdiği yeni bir sosyokültürel çevreye yabancılık çekmesi ve anomik bir ortama savrulması kaçınılmazdır. Bu nedenle, kentlileşmeyi ivedililikle gerçekleştirebilecek sihirli bir değnek hiçbir zaman bulunamayacaktır. Bireyin katıldığı farklı bir çevreye uyum sağlayabilmesi zamana bağlıdır ve iki yönlü bir çabayı gerektirmektedir:

Öncelikle kırdan gelen bireyin, kent değerlerini benimseme yönünde açık bir çaba içine girmesi, yabancılaşma ve kuralsızlığın olumsuz etkilerini azaltmada yardımcı olacaktır. Ne var ki, böylesine bir girişimin, özellikle 1. kuşak açısından hiç de kolay olmadığı yaşanan bir gerçektir. Çünkü özellikle 1 . kuşak, geldikleri yöre ile bağlarını canlı tutmakta, gerek köylerinden gelen akrabalarına zaman zaman iş bulmayı ya da sağlık kuruluşlarına götürmeyi sürdürmekte, hatta emeklilik yaşına ulaştıklarında köylerine geri dönmeyi düşünmekte ya da bunu gerçekleştirmektedirler.

Öyleyse 1. kuşak kır kökenli göçmenlerin kentlileşebileceklerini düşünmek, oldukça iyimser bir beklentidir. Bu kuşak, ayrıksı durumlar bir yana iyi bir olasılıkla yaşamlarının sonlarına doğru yarı köylü yarı kentli bir konuma ulaşabileceklerdir.

Asıl önemli olan 2. ve 3. kuşakların kentle bütünleşmelerini sağlayacak düzeneklerin kurulmasıdır. Bilinçli bir örgün ve yaygın eğitim seferberliği bu sonucu doğurabilir. Öte yandan şu gerçeğin de anımsanması gerekir ki, 2013 yılı itibarıyla yaklaşık 50 yıl önce yurttaşlarımızın çoğunluğu kentlerde değil, kırsal kesimlerde yaşıyorlardı. Ayrıca kent değerleri herhangi bir yerleşmenin il ya da ilçe yapılmasıyla hemen kendiliğinden oluşmazlar. Daha açık bir deyişle, ülkemizde bugün bile il merkezi olduğu hâlde kırsal değerlerin egemen olduğu birçok kentin bulunduğu asla unutulmamalıdır.

Kentlileşmenin hızlandırılmasında, kuşku yok ki, kentlilere de düşen görevler vardır. Kentlilerin kırsal kökenli yurttaşlarını dışlamamaları, hoşgörü ve sabırla onları kentsel değerlerle buluşturmaya çalışmaları gerekir.

İşte, ancak böylesine iki yönlü bir çaba kırsal kökenlilerin kent değerlerini benimseyerek 1. kuşakta olmasa bile hiç olmazsa 2. kuşakta kent bilincine ulaşmalarını sağlayabilir.

Özet olarak, kentlileşme yani kent değerlerini ve davranış biçimlerini benimseme, ancak belli bir zamanın geçmesiyle olanaklıdır. Başka bir deyişle kentlileşme, sosyo-kültürel bir süreçtir ve bu sürecin ortadan kaldırılması değildir; bununla birlikte kısaltılması olanaklıdır. 